J. Clin. Chem. Clin. Biochem.

Vol. 27, 1989, pp. 567-575

(C) 1989 Walter de Gruyter \& Co.

Berlin - New York

\title{
Hydrogen Peroxide and Methyl Mercury are Primary Stimuli of Eicosanoid Release in Human Platelets
}

\author{
By W. Hornberger and H. Patscheke
}

Institut für Klinische Chemie, Klinikum Mannheim der Universität Heidelberg, Mannheim, F.R.G.

(Received April 21/July 20, 1989)

Summary: Hydrogen peroxide $\left(\mathrm{H}_{2} \mathrm{O}_{2}\right)$ and methyl mercury induced the liberation of arachidonate and its metabolites from human washed platelets. $\left[{ }^{14} \mathrm{C}\right]$ Eicosanoids were extracted from the supernatants of $\left[{ }^{14} \mathrm{C}\right]$ arachidonate-prelabelled platelets and analysed by thin layer chromatography and radioscanning. Thromboxane $\mathrm{B}_{2}\left(\mathrm{TXB}_{2}\right), 12(\mathrm{~S})$-hydroxy-5,8,10-heptadecatrienoic acid (HHT) and 12(S)-hydroxy-5,8,10,14-eicosatetraenoic acid (12-HETE) were found as stable metabolites, together with unreacted arachidonate. In the presence of dazoxiben, a shift in eicosanoid metabolism was observed towards prostaglandin $\mathrm{E}_{2}\left(\mathrm{PGE}_{2}\right)$, prostaglandin $\mathrm{D}_{2}\left(\mathrm{PGD}_{2}\right)$ and prostglandin $\mathrm{F}_{2 \alpha}\left(\mathrm{PGF}_{2 \alpha}\right)$, while in the presence of indomethacin there was a shift towards 12-HETE and unmetabolized arachidonate. The concentration pattern of those metabolites resembled that found with the physiological agonist, thrombin. $\mathrm{H}_{2} \mathrm{O}_{2}$ and methyl mercury also induced platelet shape change, aggregation and secretion. The $\mathrm{EC}_{50}$ values for the induction of shape change and aggregation were 27 and $850 \mu \mathrm{mol} / 1$ for $\mathrm{H}_{2} \mathrm{O}_{2}$ and 0.33 and $2.7 \mu \mathrm{mol} / 1$ for methyl mercury, respectively. The [ $\left.{ }^{3} \mathrm{H}\right]$ serotonin release required higher stimulus concentrations and amounted to $45 \%$ with $2 \mu \mathrm{mol} / 1 \mathrm{H}_{2} \mathrm{O}_{2}$ and to $16 \%$ with $3 \mu \mathrm{mol} / 1$ methyl mercury. These effects on platelet function were absent in platelets exposed to acetylsalicylic acid and prevented by indomethacin, the prostaglandin $\mathrm{H}_{2}\left(\mathrm{PGH}_{2}\right)$ /thromboxane $\mathrm{A}_{2}\left(\mathrm{TXA}_{2}\right)$ receptor antagonist, daltroban, and the functional antagonist, iloprost. In contrast, none of these drugs suppressed the formation of $\left[{ }^{14} \mathrm{C}\right]$ eicosanoids, indicating that the platelet activation by $\mathrm{H}_{2} \mathrm{O}_{2}$ and methyl mercury essentially requires previous $\mathrm{PGH}_{2} / \mathrm{TXA}_{2}$ formation. As expected, the thromboxane synthase inhibitor, dazoxiben, did not prevent, but instead potentiated the activation by $\mathrm{H}_{2} \mathrm{O}_{2}$ and methyl mercury through accumulated $\mathrm{PGH}_{2}$. These results show that $\mathrm{H}_{2} \mathrm{O}_{2}$ and methyl mercury selectively trigger the mobilization of endogenous arachidonate. In platelets exposed to acetylsalicylic acid or in the presence of a $\mathrm{PGH}_{2} / \mathrm{TXA}_{2}$ receptor antagonist, they are model stimuli for investigating endogenous eicosanoid formation without the interference of a receptor-operated activation cascade. Therefore, $\mathrm{H}_{2} \mathrm{O}_{2}$ and methyl mercury are valuable tools for elucidating the unresolved trigger mechanisms of eicosanoid release and for studying approaches to its selective inhibition.

\section{Introduction}

The synthesis of eicosanoids in human platelets is triggered by their physiological agonists thrombin, collagen, ADP etc., but it is not essential for platelet activation by these stimuli (1). Eicosanoid release follows the stimulation of phosphatidylinositol turnover and the rise in the intracellular diacylglycerol and $\mathrm{Ca}^{2+}$ concentrations in stimulated platelets (2). $\mathrm{PGH}_{2}{ }^{1}$ ) and $\mathrm{TXA}_{2}{ }^{1}$ ) are major but unstable eicosanoids formed from endogenous arachidonate, and they play a functional role as strong feedback agonists of platelet activation (3-5). Acetylsalicylic acid (aspirin $^{\circledR}$ ) and other non-steroidal anti-inflammatory drugs reduce platelet activation, because they inhibit

\footnotetext{
1) Abbreviations:

12-HETE, 12(S)-hydroxy-5,8,10,14-eicosatetraenoic acid; HHT, 12(S)-hydroxy-5,8,10-heptadecatrienoic acid; 12-HPETE, 12(S)-hydroperoxy-5,8,10,14-eicosatetraenoic acid; PG, prostaglandin; TX, thromboxane; $\mathrm{EC}_{50}$, concentration of an agonist that produces $50 \%$ effect; TLC, thin layer chromatography.
} 
$\mathrm{PGH}_{2}$ and $\mathrm{TXA}_{2}$ formation from endogenous arachidonate released upon platelet stimulation by either of the above mentioned agonists. Antagonists acting on the $\mathrm{PGH}_{2} / \mathrm{TXA}_{2}$ receptor exert a similar inhibitory effect by preventing $\mathrm{PGH}_{2}$ and $\mathrm{TXA}_{2}$ from stimulating their common $\mathrm{PGH}_{2} / \mathrm{TXA}_{2}$ receptor (6). However, neither cyclooxygenase inhibitors nor $\mathrm{TXA}_{2} / \mathrm{PGH}_{2}$ receptor antagonists suppress the mobilization of arachidonate, which is the key event in eicosanoid formation (7). Thus, these drugs cannot prevent the mobilization and metabolism of free arachidonate to biologically active products. In particular, cyclooxygenase inhibitors like acetylsalicylic acid may enhance the formation of lipoxygenase products, such as 12 HETE $^{1}$ ) in platelets (8) and leukotrienes from plateletderived arachidonate in leukocytes (9). Therefore, there is considerable pharmacological interest in the search for inhibitors of the initiation of eicosanoid release, namely the mobilization of arachidonate.

The biochemical link between the receptor-operated activation cascade and eicosanoid release is still unknown $(10,11)$, as are specific inhibitors of the arachidonate release (12). Several enzymes regulate the free arachidonate concentration. Phospholipase $\mathrm{A}_{2}{ }^{2}$ ) supplies the major portion of free arachidonate by liberation from phospatidylcholine and to a lesser extent from phosphatidylethanolamine $(13,14)$. The sequential action of phospholipase $\mathrm{C}^{2}$ ) and diglyceride and monoglyceride lipases contributes to less than 15 percent of the arachidonate mobilized during platelet stimulation with thrombin (15). On the other hand, arachidonyl-CoA synthetase ${ }^{2}$ ) (16) and lysophospholipid acyltransferase ${ }^{2}$ ) (17) can rapidly sequester a large amount of free arachidonate-and reincorporate it into the phospholipids by the reacylating pathway (18). Therefore, the extent to which an activation of the deacylation or an inhibition of the reacylation pathway contribute to the arachidonate mobilization is the subject of an ongoing debate (19). The biochemical study of arachidonate release is difficult, because both membrane-bound enzymes and membrane-associated substrates are involved. Another problem arises from the lack of specific biochemical and pharmacological tools to interfere with the complex mechanism that controls the concentration of free arachidonate. Hydrogen peroxide $\left(\mathrm{H}_{2} \mathrm{O}_{2}\right)$ and

\footnotetext{
2) Enzymes:

Arachidonyl-CoA synthetase (EC 6.2.1.15)

Prostaglandin synthase (Cyclooxygenase) (EC 1.14.99.1)

Lactate dehydrogenase (EC 1.1.1.27)

Lipoxygenase (1.13.11.12)

Lysophospholipid acyltransferase (EC 2.3.1.23)

Phospholipase $\mathrm{A}_{2}$ (EC 3.1.1.4)

Phospholipase C (EC 3.1.4.3)

Thromboxane synthase (EC 5.3.99.5)
}

methyl mercury chloride may prove to be such tools, suitable for investigating the underlying mechanism. It is shown in the present work that both agents mobilize arachidonate, independently of the activation cascade. Thus they act more directly on eicosanoid release than thrombin or other stimuli, which require the receptor-operated activation cascade.

$\mathrm{H}_{2} \mathrm{O}_{2}$ belongs to the reactive oxygen species produced by phagocytosing or otherwise stimulated neutrophils. The amount produced by $2.5 \cdot 10^{6}$ neutrophils reaches $6 \mathrm{nmol}$ per 20 minutes $(20,21)$. A much less potent source of $\mathrm{H}_{2} \mathrm{O}_{2}$ is the platelet stimulated with latex particles or opsonized zymosan (22). In studies on the actions of $\mathrm{H}_{2} \mathrm{O}_{2}$ on platelets in vitro, different authors report on the one hand an inhibition of platelet aggregation induced by arachidonate $(21,23)$ and an inactivation of the platelet cyclooxygenase (24); and on the other hand, an enhancement by $\mathrm{H}_{2} \mathrm{O}_{2}$ of the effects of a variety of platelet agonists (25) and its role as a cosubstrate in the activation of the platelet cyclooxygenase $^{2}$ ) (26). Our own work on the role of reactive oxygen species in platelet physiology $(27,28)$ led us to use $\mathrm{H}_{2} \mathrm{O}_{2}$ as a model stimulus of platelet activation via thromboxane formation (29): While $\mathrm{H}_{2} \mathrm{O}_{2}$ represents a physiological agent, methyl mercury is formed by microorganisms from inorganic mercury in industrial waste and accumulates in man at the end of the food chain through its solubility in lipids. It causes toxic effects on brain, liver and kidneys (for review see 1.c. (30)) but its mechanism of action has not yet been clarified. Inhibitory effects of methyl mercury were described on adenylate cyclase $(31,32)$ and on 12-lipoxygenase $\left.{ }^{2}\right)(33)$, leading to a reduced inhibition of thromboxane synthesis by 12(S)hydroperoxy-5,8,10,14-eicosatetraenoic acid (12HPETE). Additionally, the whole blood glutathione peroxidase activity and total blood glutathione is decreased by methyl mercury, whereas the serum levels of $\mathrm{TXB}_{2}{ }^{1}$ ) and $\mathrm{PGE}_{1}{ }^{1}$ ) increase (34). MacFarlane (23) reported that methyl mercury induces platelet shape change, aggregation and the release reaction, and that these effects could be suppressed by an inhibition of the cyclooxygenase. The present study demonstrates that the target of $\mathrm{H}_{2} \mathrm{O}_{2}$ and methyl mercury is the mobilization of endogenous arachidonate. Thus $\mathrm{H}_{2} \mathrm{O}_{2}$ and methyl mercury are useful model substances for biochemical and pharmacological research on the initial step of eicosanoid release.

\section{Materials and Methods}

Biochemicals

Perhydrol (= hydrogen peroxide) No. 7210 and methyl mercury chloride No. 806100 were purchased from Merck (Darmstadt, F.R. G.), thrombin from Behringwerke (Marburg, F. R. G.), 
indomethacin No. I-7378 and human albumin, essentially fatty acid free, No. A-3782 from Sigma GmbH (München, F. R. G.). Dazoxiben (UK 37248) was supplied by Pfizer Central Research (Sandwich, UK), Sulotroban (BM 13.177) by Boehringer Mannheim (Mannheim, F.R.G.), lloprost (ZK 36374) by Schering AG (Berlin, F.R. G.) and LU 41.453, an inhibitor of the cyclic AMP phosphodiesterase, by Knoll AG (Ludwigshafen, F. R. G.). $\left[1-{ }^{14} \mathrm{C}\right]$ Arachidonic acid $(2.0 \mathrm{TBq} / \mathrm{mol})$ and ${ }^{3} \mathrm{H}$-labelled $\mathrm{PGF}_{2 \alpha}, \mathrm{PGE}_{2}, \mathrm{PGD}_{2}, \mathrm{TXB}_{2}$ and 12 -HETE as standards for thin layer chromatography were obtained from New England Nuclear (Dreieich, F. R. G.). [ $\left.{ }^{3} \mathrm{H}\right]$ Serotonin (5-hydroxy $\left[\mathrm{G}^{-3} \mathrm{H}\right]$ tryptamine creatinine sulphate) was obtained from Amersham Buchler (Braunschweig, F. R. G.).

\section{Preparation of washed platelets}

Blood was taken only from healthy volunteers, who all disclaimed taking any drugs during the previous week. Disc shaped washed platelets were prepared from whole blood anticoagulated with $1 / 7$ vol ACD NIH-formula A $(8 \mathrm{~g} / 1$ citric acid, 22 $\mathrm{g} / \mathrm{l}$ sodium citrate, $24.5 \mathrm{~g} / \mathrm{l}$ hydrous dextrose) according to our method of washing with acid citrate (35). The platelets were sedimented from platelet-rich plasma by $7 \mathrm{~min}$ centrifugation at $330 \mathrm{~g}$ and resuspended in a solution containing $\mathrm{NaCl} 120$ $\mathrm{mmol} / \mathrm{l}, \mathrm{KCl} 5 \mathrm{mmol} / 1, \mathrm{CaCl}_{2} 2 \mathrm{mmol} / \mathrm{l}, \mathrm{MgCl}_{2} 1 \mathrm{mmol} / 1$, glucose $5 \mathrm{mmol} / 1$, albumin $2 \mathrm{~g} / \mathrm{l}$, apyrase $50 \mathrm{mg} / 1$, sodium phosphate/ $\mathrm{NaOH} 30 \mathrm{mmol} / \mathrm{l}, \mathrm{pH} 6.5$. When platelets were treated with acetylsalicylic acid $5 \mathrm{mmol} / \mathrm{l}$, a freshly prepared solution of $20 \mathrm{mmol} / 1$ in isotonic TES buffer $\mathrm{pH} 7.4$ was added to the platelet-rich plasma and incubated for $30 \mathrm{~min}$ at $22^{\circ} \mathrm{C}$ prior to the washing procedure. Where platelet secretion was to be measured, platelet-rich plasma was incubated with $0.08 \mu \mathrm{mol} / 1$ $(\approx 60 \mathrm{kBq})\left[{ }^{3} \mathrm{H}\right]$ serotonin for $10 \mathrm{~min}$ at $22^{\circ} \mathrm{C}$ in order to label the secretory dense bodies. This procedure could be performed separately or in combination with acetylsalicylic acid treatment. The washed platelets were finally suspended in a test medium containing $\mathrm{NaCl} 120 \mathrm{mmol} / \mathrm{l}, \mathrm{KCl} 5 \mathrm{mmol} / \mathrm{l}, \mathrm{CaCl}_{2} 1 \mathrm{mmol} / \mathrm{l}$, $\mathrm{MgCl}_{2} 0.1 \mathrm{mmol} / 1$, glucose $5 \mathrm{mmol} / 1$, albumin $0.5 \mathrm{~g} / \mathrm{l}$, apyrase $50 \mathrm{mg} / \mathrm{l}$, sodium phosphate $1 \mathrm{mmol} / \mathrm{l}$, TES $/ \mathrm{NaOH} 30 \mathrm{mmol} / \mathrm{l}$, $\mathrm{pH}$ 7.4. The final platelet concentrations were $200 \cdot 10^{9} / 1$ for the measurements of platelet shape change, aggregation and $\left[{ }^{3} \mathrm{H}\right]$ serotonin release and $2 \cdot 10^{12} / 1$ for the measurement of $\left[{ }^{14}\right.$ C]eicosanoid metabolism.

Rheooptical measurements of shape change and aggregation

Shape change and aggregation were measured turbidimetrically in a dual channel aggregometer (Labor, Ahrensburg, F. R. G.) at $37^{\circ} \mathrm{C}$ by the method established by Born (36) with modifications as published earlier (35). Shape change experiments were performed in the presence of EDTA $2 \mathrm{mmol} / \mathrm{l}$ at a stirring speed of $400 \mathrm{~min}^{-1}$. In aggregation experiments, $300 \mathrm{mg} / \mathrm{l}$ of fibrinogen were added and the stirring speed was $1000 \mathrm{~min}^{-1}$. Preincubation of platelet suspensions with test substances started 5 minutes prior to stimulation. The instrumental arrangement for measurements and the quantification of shape change and aggregation were described previously (35).

\section{Release of $\left[{ }^{3} \mathrm{H}\right]$ serotonin}

The secretion of $\left[{ }^{3} \mathrm{H}\right]$ serotonin from platelet dense granules was determined as the decrease of the platelet bound radioactivity (35). The reuptake of serotonin was inhibited by the presence of imipramine $2 \mu \mathrm{mol} / 1$. Aliquots were taken from incubates three minutes after addition of the activating agent and were mixed with $50 \mu$ l of an $0.1 \mathrm{mmol} / 1$ ice-cold EDTA solution $\mathrm{pH}$ 7.4, rapidly cooled to $0^{\circ} \mathrm{C}$ and centrifuged for $30 \mathrm{~s}$ in an Eppendorf 3200 centrifuge at $0^{\circ} \mathrm{C}$. The radioactivity of $200 \mu \mathrm{l}$ aliquots of the supernatant was counted in a liquid scintillation counter.

\section{Platclet prelabelling with $\left[{ }^{14} \mathrm{C}\right]$ arachidonate}

For radiochemical assays, the washed platelets were prelabelled with $\left[{ }^{14} \mathrm{C}\right]$ arachidonate. For this purpose platelets $\left(200 \cdot 10^{9} / 1\right)$ were resuspended in a buffer containing $\mathrm{NaCl} 120 \mathrm{mmol} / \mathrm{l}, \mathrm{KCl}$ $5 \mathrm{mmol} / \mathrm{l}, \mathrm{MgCl}_{2} 1 \mathrm{mmol} / 1, \mathrm{CaCl}_{2} 2 \mathrm{mmol} / 1$, human albumin $2 \mathrm{~g} / \mathrm{l}$, glucose $5 \mathrm{mmol} / \mathrm{l}$ and apyrase $50 \mathrm{mg} / \mathrm{l}$ in phosphate-buffer $30 \mathrm{mmol} / \mathrm{l}, \mathrm{pH}$ 6.5. $\left[{ }^{4} \mathrm{C}\right]$ Arachidonate was dissolved in the same buffer by sonification for 2 minutes. The platelets were incubated with $\left[{ }^{14} \mathrm{C}\right]$ arachidonate $3.25 \mu \mathrm{mol} / 1$ for one hour at $37^{\circ} \mathrm{C}$. Arachidonate was added in 10 portions at $6 \mathrm{~min}$ intervals in order to avoid platelet activation. Then the platelets were washed twice to remove remaining free arachidonate and finally resuspended in test buffer containing $\mathrm{NaCl} 120 \mathrm{mmol} / \mathrm{l}, \mathrm{KCl}$ $5 \mathrm{mmol} / 1, \mathrm{MgCl}_{2} 0.2 \mathrm{mmol} / \mathrm{l}, \mathrm{CaCl}_{2} 1.2 \mathrm{mmol} / \mathrm{l}$, human albumin $0.5 \mathrm{~g} / \mathrm{l}$ (if not stated otherwise), glucose $5 \mathrm{mmol} / \mathrm{l}$, phosphate $6 \mathrm{mmol} / \mathrm{l}$, and apyrase $50 \mathrm{mg} / \mathrm{l}$ in $0.1 \mathrm{~mol} / 1 \mathrm{TES} / \mathrm{HCl}$, pH 7.4. The final platelet concentration was $2 \cdot 10^{12} / 1$.

\section{Radiochemical assays}

Samples of platelets $(980 \mu \mathrm{l})$ prelabelled with $\left[{ }^{14} \mathrm{C}\right]$ arachidonate were warmed to $37^{\circ} \mathrm{C}$ for 5 minutes. Drug solutions $(10 \mu \mathrm{l})$ were added and after another 5 minutes, platelet stimuli were applied in a volume of $10 \mu \mathrm{l}$. The final test volume was $1 \mathrm{ml}$. In the controls, test medium was added instead of drugs. After the desired time of incubation, the reaction was stopped by acidifying to $\mathrm{pH} 3$ with $10 \mu \mathrm{l}$ of concentrated formid acid. Samples were centrifuged at $10000 \mathrm{~g}$ for 15 minutes and the cell-free supernatants extracted twice with ethyl acetate. The combined organic phases were dried under nitrogen, redissolved in $100 \mu \mathrm{l}$ of chloroform/methanol $(2+1$, by vol.) and analysed by thin layer chromatography. The overall recovery of the radioactivity in the extracts and the platelet sediments averaged 86 percent of the platelet-bound radioactivity after prelabelling.

\section{Analysis of $\left[{ }^{14} \mathrm{C}\right]$ eicosanoids by radioT $\left.L C^{1}\right)$}

Silica gel TLC-plates (No. 11798, Merck, Darmstadt, F. R. G.) were heated to $110^{\circ} \mathrm{C}$ for 15 minutes and subsequently allowed to cool in a desiccator. After application, the plates were developed by a solvent system consisting of chloroform/methanol/ acetic acid/water $(87+8+4+1$, by vol.), which resolved well the comigrating authentic standards of 12-HETE, prostaglandins and thromboxane $B_{2}$ (fig. 1). The radioactive spots on the TLC-plate were evaluated by a Berthold LB 2842 TLC-linear analyser (Berthold, Wildbad, F.R.G.) with integration software. After peak integration and background subtraction the percentage of radioactivity was calculated for each compound. The liberation of radiolabelled eicosanoids was determined by liquid scintillation counting of aliquots taken from the test suspension and cell-free supernatant. The extracts of the sediments were free of $\left[{ }^{14} \mathrm{C}\right]$ eicosanoids.

\section{Release of lactate dehydrogenase}

As a parameter of cytoplasmic leakage, lactate dehydrogenase ${ }^{2}$ ) was measured in an optical test (Monotest, Boehringer Mannheim, Mannheim, F. R.G.). Aliquots were taken from the incubates five minutes after the addition of $\mathrm{H}_{2} \mathrm{O}_{2}$ or methyl mercury, and the supernatants prepared by centrifugation for $30 \mathrm{~s}$ in an Eppendorf 3200 centrifuge at $0^{\circ} \mathrm{C}$. The lactate dehydrogenase in the supernatants was compared with the total lactate dehydrogenase released from control platelets after their lysis by three cycles of freezing and thawing.

\section{Statistics}

Data are expressed as mean \pm S. E. M. Statistical comparisons were performed using Student's t-test for paired data. The null hypothesis was rejected if $p<0.05$. The concentration effect 
curves were calculated from data points by multiple iterations using a non-linear sigmoidal least squares regression fit algorithm developed by Marquardt (37) and improved by Tabata \& Ito (38). The algorithm is part of the statistics and plotter graphics software package GRAPHPAD from ISI (USA).

\section{Results}

Treatment of $\left[{ }^{14} \mathrm{C}\right]$ arachidonate-prelabelled platelets with hydrogen peroxide $\left(\mathrm{H}_{2} \mathrm{O}_{2}\right)$ or methyl mercury led to the release of radiolabelled metabolites and unreacted arachidonate. The major $\left[{ }^{14} \mathrm{C}\right]$ eicosanoids were $\mathrm{TXB}_{2}{ }^{1}$ ), $\mathrm{HHT}^{1}$ ) and 12-HETE ${ }^{1}$ ) which appeared in the same relative amounts and representing the same percentage of the liberated $\left[{ }^{14} \mathrm{C}\right]$ eicosanoids, irrespective of whether the platelets were stimulated with $\mathrm{H}_{2} \mathrm{O}_{2}$, methyl mercury or thrombin (fig. 1 and tab. 1). With $\mathrm{H}_{2} \mathrm{O}_{2}$, a rise in the liberation of $\left[{ }^{14} \mathrm{C}\right]$ eicosanoids continued up to $30 \mathrm{mmol} / \mathrm{l}$, but beyond $1 \mathrm{mmol} / 1 \mathrm{H}_{2} \mathrm{O}_{2}$ the amount of $\mathrm{TXB}_{2}$ and $\mathrm{HHT}$ decreased in favour of unreacted arachidonate and 12-HETE (fig. 2). The optimal concentration of $\mathrm{H}_{2} \mathrm{O}_{2}$ for the stimulation of $\mathrm{TXB}_{2}$ formation was approximately $1 \mathrm{mmol} / \mathrm{l}$, which induced the liberation of 4.5 $\pm 0.4 \%(n=5)$ of the platelet-bound radioactivity (fig. 2). With methyl mercury $20 \mu \mathrm{mol} / 1$ and thrombin $10^{3} \mathrm{IU} / 1$, the liberation of $\left[{ }^{14} \mathrm{C}\right]$ eicosanoids amounted to $5.6 \pm 0.3 \%(n=3)$ and $7.2 \pm 0.5 \%(n=3)$ of the platelet-bound radioactivity, respectively. Inhibitors of the cyclooxygenase, such as acetylsalicylic acid or indomethacin (tab. 1), suppressed the TXB ${ }_{2}$ and HHT formation and increased the formation of the 12 lipoxygenase product, 12-HETE, but did not inhibit the $\left[{ }^{14} \mathrm{C}\right]$ eicosanoid release $(5.6 \pm 0.3 \%$ vs. 4.9 $\pm 0.5 \%, \mathrm{p}>0.1$ for methyl mercury and $4.4 \pm 0.4 \%$ vs. $4.1 \pm 0.3 \%, p>0.1$ for $\mathrm{H}_{2} \mathrm{O}_{2}$ ). The thromboxane synthase $^{2}$ ) inhibitor, dazoxiben, shifted the $\left[{ }^{14} \mathrm{C}\right]$ eicosanoid metabolism from $\mathrm{TXB}_{2}$ and HHT to the stable prostaglandins, $\left.\mathrm{PGE}_{2}{ }^{1}\right), \mathrm{PGD}_{2}{ }^{1}$ ) and $\mathrm{PGF}_{2 \alpha}{ }^{1}$ ) (tab. 1), which are spontaneously formed from the labile prostaglandin, endoperoxide $\mathrm{PGH}_{2}(2$, 39,40 ). Iloprost and LU 41.453, which are functional antagonists in platelets, prevented the thrombin-induced $\left[{ }^{14} \mathrm{C}\right]$ eicosanoid release, but had no effect on the $\left[{ }^{14} \mathrm{C}\right]$ eicosanoid formation triggered by methyl mercury (tab. 2).

$\mathrm{H}_{2} \mathrm{O}_{2}$ and methyl mercury caused platelet activation as indicated by shape change, aggregation and $\left[{ }^{3} \mathrm{H}\right]$ serotonin release. The concentration-effect relationships of the shape change and the aggregation are shown on figure $3 a$ and $b$. The $\left[{ }^{3} \mathrm{H}\right]$ serotonin release required the highest stimulus concentrations and it amounted to approximately $45 \%$ with $2 \mathrm{mmol} / 1 \mathrm{H}_{2} \mathrm{O}_{2}$ (fig. $4 \mathrm{a}$ ) and $16 \%$ with $3 \mu \mathrm{mol} / 1$ methyl mercury (fig. $4 \mathrm{~b}$ ) in platelets aggregating in the presence of fibri-

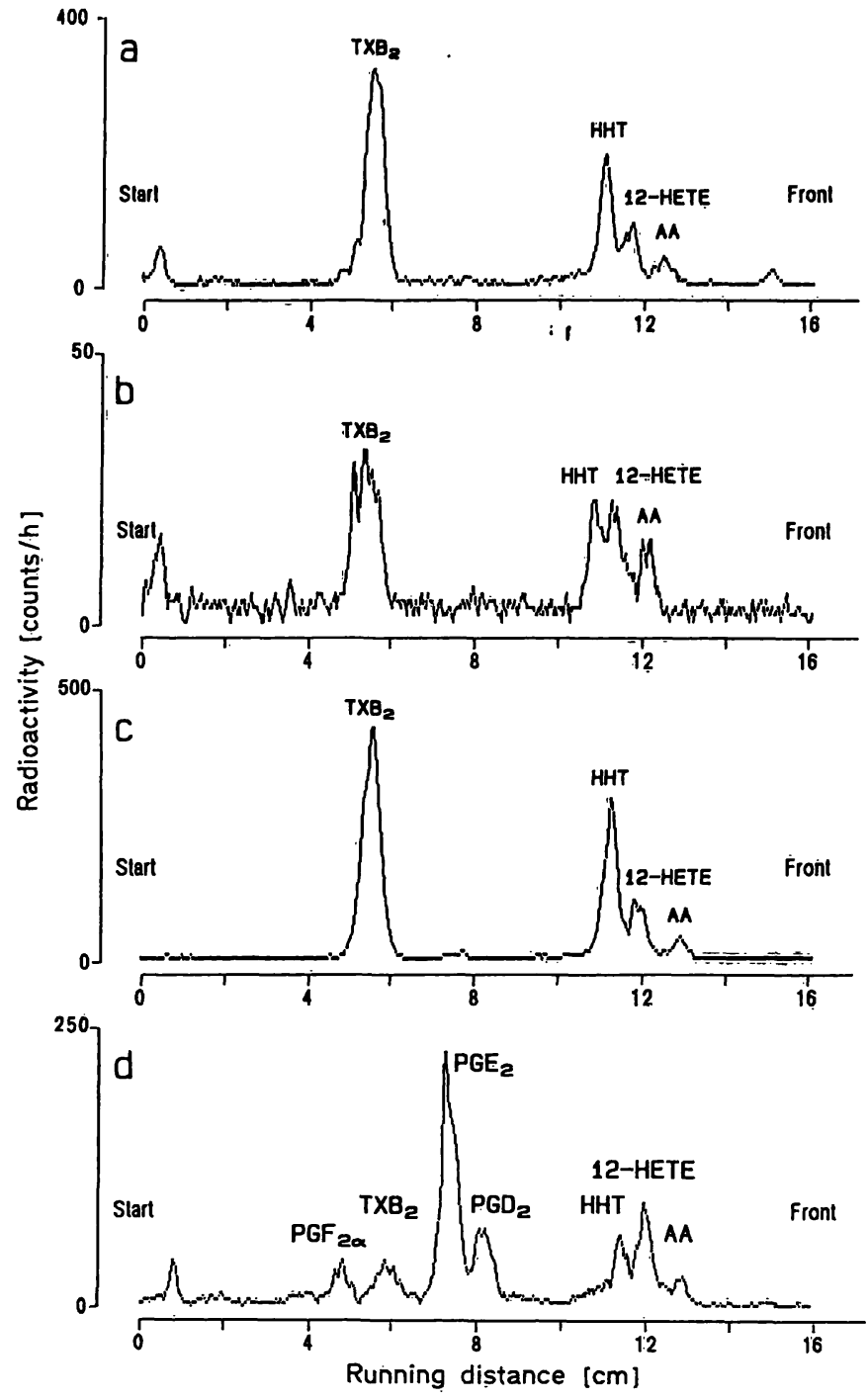

Fig. 1. Thin layer radiochromatograms of $\left[{ }^{14} \mathrm{C}\right]$ eicosanoids in supernatants from human platelets prelabelled with $\left[{ }^{14} \mathrm{C}\right]$ arachidonate and stimulated for 1 minute with (a) methyl mercury $20 \mu \mathrm{mol} / \mathrm{l}$, (b) hydrogen peroxide 1 $\mathrm{mmol} / \mathrm{l}$, (c) thrombin $10^{3} \mathrm{IU} / \mathrm{l}$ and (d) with methyl mercury $20 \mu \mathrm{mol} / 1$ in the presence of dazoxiben 10 $\mu \mathrm{mol} / 1$.

$\mathrm{TXB}_{2} \cong$ thromboxane $\mathrm{B}_{2}$

HHT = 12(S)-hydroxy-5,8,10-heptadecatrienoic acid

12-HETE = 12(S)-hydroxy-5,8,10,14-eicosatetraenoic acid

$\mathrm{AA}=$ arachidonic acid

$\mathrm{PGF}_{2 \alpha}=$ prostaglandin $\mathrm{F}_{2 \alpha}$

$\mathrm{PGE}_{2}=$ prostaglandin $\mathrm{E}_{2}$

$\mathrm{PGD}_{2}=$ prostaglandin $\mathrm{D}_{2}$

nogen. If aggregation was prevented by EDTA $2 \mathrm{mmol} / \mathrm{l},\left[{ }^{3} \mathrm{H}\right]$ serotonin release decreased to $20 \%$ and $3 \%$ (fig. $4 \mathrm{a}$ and $4 \mathrm{~b}$ ), respectively, whereas a full shape change remained unaffected. $\mathrm{H}_{2} \mathrm{O}_{2}$ was used at concentrations not higher than $2 \mathrm{mmol} / \mathrm{l}$ in functional tests, since at higher concentrations it released small bubbles of molecular oxygen that severely interfered with the turbidimetric measurements of shape change and aggregation. The aggregating effect of methyl 
Tab. 1. Effects of hydrogen peroxide, methyl mercury and thrombin on the formation of $\left[{ }^{14} \mathrm{C}\right]$ metabolites in platelets prelabelled with $\left[{ }^{14} \mathrm{C}\right]$ arachidonate. The platelets were stimulated for 1 minute in the absence $(=$ control) or the presence of dazoxiben, daltroban or indomethacin. Platelet concentration: $200 \cdot 10^{9} / 1$.

12-HETE $=12$ (S)-hydroxy-5,8,10,14-eicosatetraenoic acid

HHT $=12$ (S)-hydroxy-5,8,10-heptadecatrienoic acid

\begin{tabular}{lllllll}
{$\left[{ }^{14} \mathrm{C}\right]$ Eicosanoids (percent } & \multicolumn{2}{l}{ total eicosanoids released) } \\
\hline Prosta- & Thromb- & Prosta- & Prosta- & HHT & 12-HETE & Arachi- \\
glandin & oxane & glandin & glandin & & & donic \\
$\mathrm{F}_{2 \alpha}$ & $\mathrm{B}_{2}$ & $\mathrm{E}_{2}$ & $\mathrm{D}_{2}$ & & & acid
\end{tabular}

Hydrogen peroxide $1 \mathrm{mmol} / \mathrm{l}$

\begin{tabular}{|c|c|c|c|c|c|c|c|c|}
\hline $\begin{array}{l}\text { Control } \\
\text { Dazoxiben } 50 \mu \mathrm{mol} / 1 \\
\text { Indomethacin } 50 \mu \mathrm{mol} / 1\end{array}$ & $\begin{array}{l}0 \\
0.9 \pm 0.3 \\
0\end{array}$ & $\begin{array}{l}31.1 \pm 3.3 \\
0 \\
0\end{array}$ & $\begin{array}{c}0 \\
22.7 \\
0\end{array}$ & $\begin{array}{l}0 \\
3.6 \pm 1.0 \\
0\end{array}$ & $\begin{array}{l}18.4 \pm 0.6 \\
0 \\
0\end{array}$ & $\begin{array}{l}22.7 \pm 2.1 \\
36.8 \pm 2.5 \\
66.4 \pm 6.8\end{array}$ & $\begin{array}{l}27.9 \pm 2.5 \\
36.0 \pm 4.7 \\
33.7 \pm 4.9\end{array}$ & $\begin{array}{l}(\mathrm{n}=5) \\
(\mathrm{n}=3) \\
(\mathrm{n}=3)\end{array}$ \\
\hline \multicolumn{9}{|l|}{ Methyl mercury $20 \mu \mathrm{mol} / 1$} \\
\hline $\begin{array}{l}\text { Control } \\
\text { Dazoxiben } 50 \mu \mathrm{mol} / 1 \\
\text { Indomethacin } 50 \mu \mathrm{mol} / 1 \\
\text { Daltroban } 20 \mu \mathrm{mol} / 1\end{array}$ & $\begin{array}{c}0 \\
5.4 \pm 2.1 \\
0 \\
0\end{array}$ & $\begin{aligned} 38.3 & \pm 3.5 \\
1.4 & \pm 0.8 \\
0 & \\
40.6 & \pm 5.6\end{aligned}$ & $\begin{array}{l}3.0 \pm 1.1 \\
42.3 \pm 2.5 \\
0 \\
4.0 \pm 1.5\end{array}$ & $\begin{array}{c}0 \\
10.0 \pm 1.1 \\
0 \\
0\end{array}$ & $\begin{array}{l}22.5 \pm 2.1 \\
0 \\
0 \\
28.7 \pm 2.3\end{array}$ & $\begin{array}{l}29.5 \pm 2.4 \\
34.2 \pm 1.6 \\
61.1 \pm 8.4 \\
18.7 \pm 5.9\end{array}$ & $\begin{array}{r}6.8 \pm 1.6 \\
6.8 \pm 1.3 \\
39.0 \pm 5.6 \\
8.0 \pm 2.0\end{array}$ & $\begin{array}{l}(\mathrm{n}=6) \\
(\mathrm{n}=4) \\
(\mathrm{n}=3) \\
(\mathrm{n}=3)\end{array}$ \\
\hline \multicolumn{9}{|l|}{ Thrombin $10^{3} \mathrm{IU} / 1$} \\
\hline $\begin{array}{l}\text { Control } \\
\text { Dazoxiben } 50 \mu \mathrm{mol} / 1 \\
\text { Indomethacin } 50 \mu \mathrm{mol} / 1\end{array}$ & $\begin{array}{l}0 \\
2.5 \pm 0.3 \\
0\end{array}$ & $\begin{array}{l}26.4 \pm 3.3 \\
0 \\
0\end{array}$ & $\begin{array}{r}1.8 \pm 0.4 \\
33.5 \pm 6.4 \\
0\end{array}$ & $\begin{array}{l}0 \\
10.9 \pm 1.8 \\
0\end{array}$ & $\begin{array}{l}27.5 \pm 3.5 \\
0 \\
0\end{array}$ & $\begin{array}{l}22.2 \pm 3.0 \\
28.9 \pm 4.5 \\
73.3 \pm 2.7\end{array}$ & $\begin{array}{l}22.2 \pm 3.2 \\
24.3 \pm 1.0 \\
26.4 \pm 2.8\end{array}$ & $\begin{array}{l}(\mathrm{n}=3) \\
(\mathrm{n}=3) \\
(\mathrm{n}=3)\end{array}$ \\
\hline
\end{tabular}

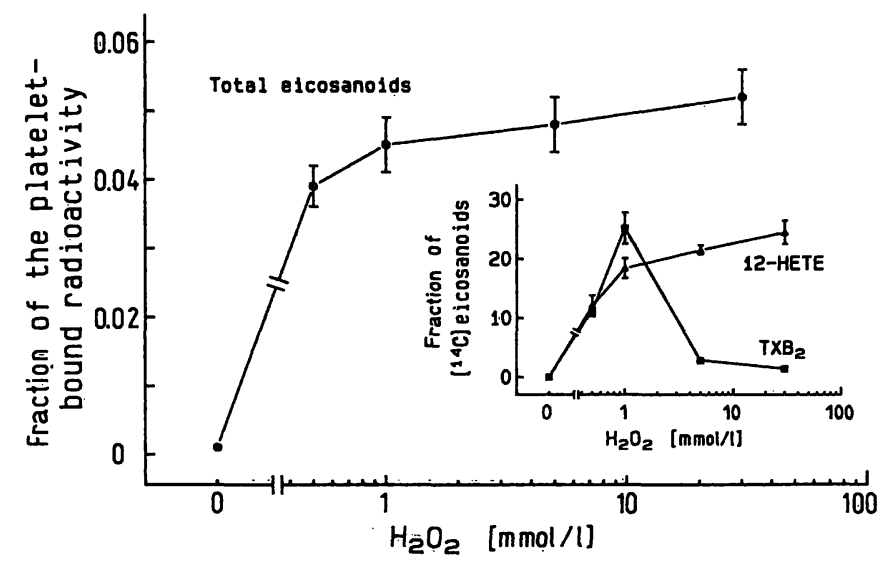

Fig. 2. Effect of hydrogen peroxide $(0.5-30 \mathrm{mmol} / \mathrm{l})$ on the liberation of $\left[{ }^{14} \mathrm{C}\right]$ eicosanoids from platelets prelabelled with $\left[{ }^{14} \mathrm{C}\right]$ arachidonate. The incubation time was $1 \mathrm{~min}-$ ute. The formation of $\left[{ }^{14}\right]$ eicosanoids is given as fraction of the platelet-bound radioactivity. Inset: Formation of $\left[{ }^{14} \mathrm{C}\right] \mathrm{TXB}_{2}$ and $\left[{ }^{14} \mathrm{C}\right] 12-\mathrm{HETE}$ as fraction of the total $\left[{ }^{14} \mathrm{C}\right]$ eicosanoids released. $\mathbf{n}=3$.

$\mathrm{TXB}_{2}=$ thromboxane $\mathrm{B}_{2}$

12-HETE $=12($ S)-hydroxy-5,8,10,14-eicosatetraenic acid.

Tab. 2. Effect of iloprost and LU 41.453 on the $\left[{ }^{14} \mathrm{C}\right]$ eicosanoid release induced by methyl mercury and thrombin. The $\left[{ }^{14} \mathrm{C}\right]$ arachidonate-prelabelled platelets were stimulated for $2 \mathrm{~min}$. Liberated radioactivity is given as the percentage of the platelet=bound radioactivity.

\begin{tabular}{lll}
\hline & \multicolumn{2}{l}{ Release of $\left[{ }^{14}\right.$ C]eicosanoids (\%) } \\
\cline { 2 - 3 } & $\begin{array}{l}20 \mu \mathrm{mol} / \mathrm{l} \\
(\mathrm{n}=3)\end{array}$ & $\begin{array}{l}\text { Thrombin } \\
(\mathrm{n}=3 \mathrm{IU} / 1\end{array}$ \\
\hline Control & $5.3 \pm 0.5$ & $4.0 \pm 0: 3$ \\
Iloprost $50 \mathrm{nmol} / \mathrm{l}$ & $4.6 \pm 0.3$ & $0.21 \pm 0: 03$ \\
LU. $41.4531 \mu \mathrm{mol} / \mathrm{l}$ & n.s. & $\mathrm{p}<0.01$ \\
\hline
\end{tabular}

mercury strongly depended on the platelet concentration. Equipotent concentrations were $3 \mu \mathrm{mol} / 1$ with $200 \cdot 10^{9} / 1$ and $20 \mu \mathrm{mol} / 1$ with $2 \cdot 10^{12} / 1$ platelets, as used in the experiments on platelet function and metabolism, respectively.

In the presence of indomethacin and in platelets pretreated with acetylsalicylic acid, both $\mathrm{H}_{2} \mathrm{O}_{2}$ ( $\leq 2 \mathrm{mmol} / \mathrm{l}$ ) and methyl mercury $(\leq 3 \mu \mathrm{mol} / \mathrm{l})$ produced neither shape change nor aggregation and $\left[{ }^{3} \mathrm{H}\right]$ serotonin release (tab. 3 ), whereas they still liberated eicosanoids (tab. 1). The same results were obtained with the $\mathrm{TXA}_{2} / \mathrm{PGH}_{2}$-receptor antagonist, sulotroban, and the functional antagonists, iloprost plus LU 41.453 (tab. 2 and 3). In contrast, the thromboxane synthase inhibitor, dazoxiben, augmented the platelet responses to $\mathrm{H}_{2} \mathrm{O}_{2}$ and methyl mercury (tab. 3).

In order to detect a cytolytic effect of $\mathrm{H}_{2} \mathrm{O}_{2}$ and methyl mercury, lactate dehydrogenase was measured in the platelet supernatants after $5 \mathrm{~min}$ incubation of 200 $\cdot 10^{9} / 1$ or $2 \cdot 10^{12} / 1$ platelets with various concentrations of those agents. Even with the highest concentrations tested $\left(30 \mathrm{mmol} / \mathrm{l}\right.$ for $\mathrm{H}_{2} \mathrm{O}_{2}$ and $0.1 \mathrm{mmol} / \mathrm{l}$ for methyl mercury), free lactate dehydrogenase did not exceed $3 \%$ with $\mathrm{H}_{2} \mathrm{O}_{2}$ and $4 \%$ with methyl mercury of the total platelet lactate dehydrogenase activity. In control experiments neither $\mathrm{H}_{2} \mathrm{O}_{2}(1$ and $10 \mathrm{mmol} / \mathrm{l})$ nor methyl mercury $(0.01$ and $0.1 \mathrm{mmol} / \mathrm{l})$ inhibited the lactate dehydrogenase in the platelet lysate. 

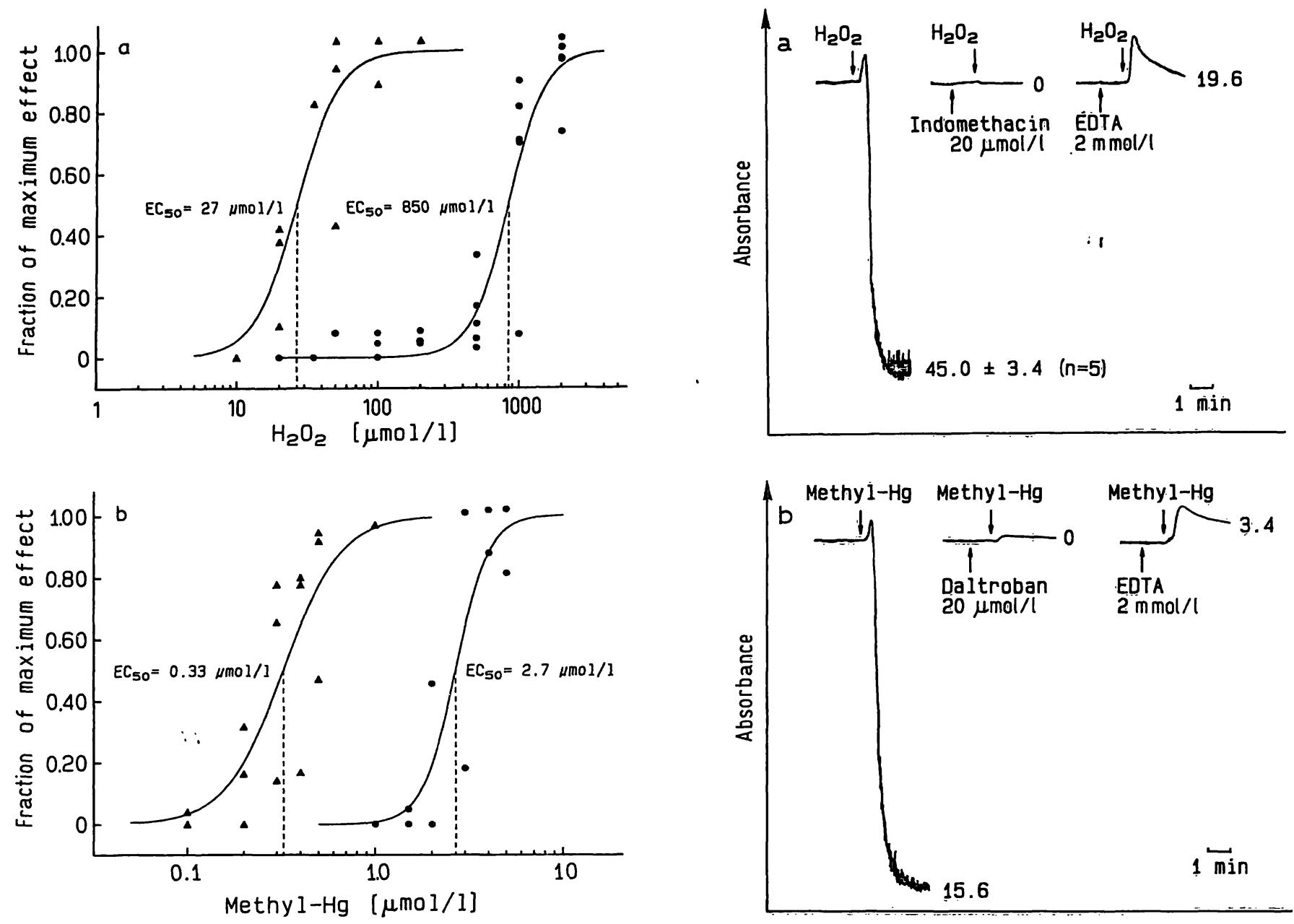

Fig. 3. Concentration effect curves for the shape change $(\boldsymbol{\Delta}-\boldsymbol{\Delta})$ and the aggregation $(\boldsymbol{0}-\boldsymbol{0})$ induced by (a) hydrogen peroxide and (b) methyl mercury (methyl-Hg). The symbols represent the means of 3-4 experiments in 3 independent experimental series. A sigmoidal, three parameter logistic function was calculated from the data by multiple iterations with a computer program. The bottom value was set constant to 0 , and the top value, $\log \left(\mathrm{EC}_{50}\right)$ and the slope were estimated after multiple iterations. The original values for the effects were then normalized by means of the estimated top value $(=1.00)$.

Fig. 4. Effects of indomethacin, daltroban and EDTA on platelet shape change, aggregation and $\left[{ }^{3} \mathrm{H}\right]$ serotonin release induced by (a) hydrogen peroxide and (b) methyl mercury (methyl-Hg). The platelet-suspending medium contained fibrinogen $300 \mathrm{mg} / \mathrm{l}$.

a: Platelet activation induced by $\mathrm{H}_{2} \mathrm{O}_{2}(2 \mathrm{mmol} / \mathrm{l})$; left side: control;

middle: indomethacin prevents any platelet response; right side: EDTA suppresses aggregation and reduces $\left[{ }^{3} \mathrm{H}\right]$ serotonin release, while a full shape change remains unaffected.

b: Platelet activation induced by methyl mercury ( 20 $\mu \mathrm{mol} / \mathrm{l})$;

left side: control;

middle: the thromboxane receptor antagonist daltroban prevents any platelet response;

right side: EDTA abolishes aggregation and diminishes $\left[{ }^{3} \mathrm{H}\right]$ serotonin release without affecting the shape change. The numbers at the ends of the curves indicate the percentage of $\left[{ }^{3} \mathrm{H}\right]$ serotonin release.

Tab. 3. Effect of indomethacin, dazoxiben and solutroban on shape change, aggregation and $\left[{ }^{3} \mathrm{H}\right]$ serotonin release induced by various concentrations of $\mathrm{H}_{2} \mathrm{O}_{2}$ and methyl mercury (methyl- $\mathrm{Hg}$ ). $\left[{ }^{3} \mathrm{H}\right]$ Serotonin release was determined upon stimulation in the presence of EDTA $2 \mathrm{mmol} / \mathrm{l}$ to avoid aggregation. $\mathrm{n}=5$.

\begin{tabular}{|c|c|c|c|c|c|}
\hline & \multicolumn{2}{|c|}{ Shape change $(\%)$} & \multicolumn{2}{|c|}{ Aggregation (\%) } & \multirow{2}{*}{$\begin{array}{l}{\left[{ }^{3} \mathrm{H}\right] \text { Serotonin }} \\
\text { release }(\%) \\
\mathrm{H}_{2} \mathrm{O}_{2} \\
2 \mathrm{mmol} / \mathrm{l}\end{array}$} \\
\hline & $\begin{array}{l}\mathrm{H}_{2} \mathrm{O}_{2} \\
500 \mu \mathrm{mol} / 1\end{array}$ & $\begin{array}{l}\text { Methyl- } \mathrm{Hg} \\
0.5 \mu \mathrm{mol} / 1\end{array}$ & $\begin{array}{l}\mathrm{H}_{2} \mathrm{O}_{2} \\
1 \mathrm{mmol} / 1\end{array}$ & $\begin{array}{l}\text { Methyl-Hg } \\
5 \mu \mathrm{mol} / \mathrm{l}\end{array}$ & \\
\hline $\begin{array}{l}\text { Control } \\
\text { Indomethacin } 20 \mu \mathrm{mol} / 1 \\
\text { Dazoxiben } 20 \mu \mathrm{mol} / 1 \\
\text { Sulotroban } 20 \mu \mathrm{mol} / 1\end{array}$ & $\begin{array}{c}69.6 \pm 3.3 \\
0 \\
99.7 \pm 0.6 \\
0\end{array}$ & $\begin{array}{l}69.5 \pm 9.2 \\
0 \\
97.0 \pm 4.8 \\
0\end{array}$ & $\begin{array}{l}68.3 \pm 1.0 \\
0 \\
79.9 \pm 4.1 \\
0\end{array}$ & $\begin{array}{c}63.6 \pm 2.3 \\
0 \\
79.8 \pm 5.6 \\
0\end{array}$ & $\begin{array}{l}22.1 \pm 1.6 \\
<1 \\
56.5 \pm 3.2 \\
<1\end{array}$ \\
\hline
\end{tabular}




\section{Discussion}

$\mathrm{H}_{2} \mathrm{O}_{2}$ and methyl mercury share with thrombin the ability to induce a platelet activation accompanied by the formation of the platelet-derived eicosanoids arachidonate, $\mathrm{TXB}_{2}, \mathrm{HHT}$ and 12-HETE. They appear in the same concentration ratios with either stimulus, showing that the metabolism of free arachidonate follows its normal routes via 12-lipoxygenase ${ }^{2}$ ) to 12 HETE and via cyclooxygenase ${ }^{2}$ ) and thromboxane synthase ${ }^{2}$ ) to $\mathrm{PGH}_{2}$ and $\mathrm{TXA}_{2}$; the stable but inactive $\mathrm{TXB}_{2}$ and HHT arise from the latter two compounds $(41,42)$. The unstable intermediary products, $\mathrm{PGH}_{2}$ and $\mathrm{TXA}_{2}$, cause shape change, aggregation and secretion, which can be suppressed by inhibitors of their formation such as acetylsalicylic acid and indomethacin, or by inhibitors of their action such as the $\mathrm{PGH}_{2} /$ $\mathrm{TXA}_{2}$ receptor antagonists, sulotroban (43) and daltroban (44). The thromboxane synthase inhibitor, dazoxiben, enhances the platelet response (29) due to accumulated $\mathrm{PGH}_{2}$, which shares the same receptor as TXA $_{2}$ (45). Acetylsalicylic acid (46) or daltroban reduce but never suppress the platelet responses to thrombin, ADP, platelet activating factor, serotonin or the stable thromboxane mimetic U 46619 (1). In contrast, acetylsalicylic acid, sulotroban and daltroban prevented the platelet stimulation by $\mathrm{H}_{2} \mathrm{O}_{2}$ and methyl mercury. Therefore, platelet stimulation by $\mathrm{H}_{2} \mathrm{O}_{2}$ and methyl mercury essentially requires the formation and action of $\mathrm{PGH}_{2}$ and $\mathrm{TXA}_{2}$, whereas each of the other mentioned agonists also elicits a platelet response independently of $\mathrm{PGH}_{2}$ and $\mathrm{TXA}_{2}$ formation. This implicates different mechanisms for triggering eicosanoid formation with $\mathrm{H}_{2} \mathrm{O}_{2}$ or methyl mercury and with the other physiological agonists.

Thrombin, ADP, platelet activating factor, serotonin and $U 46619$ act on platelets via specific receptors. Their platelet-activating signal is transmitted by an activation of the phospholipase $\mathrm{C}$ and the formation of inositol-1,4,5-trisphosphate and diacylglycerol, which increase the intracellular free $\mathrm{Ca}^{2+}$ concentration and activate protein kinase $C$, respectively (47, 48). These events lead to shape chänge, aggregation and secretion and can be inhibited by agents that stimulate the cyclic AMP formation, such as prostacyclin $(49,50)$. Therefore, agents capable of stimulating cAMP accumulation can be expected to inhibit the thrombin-induced eicosanoid release, if this release depends on the thrombin-induced activation cascade. In fact, the stable prostacyclin mimetic, iloprost (51), and the cyclic AMP phosphodiesterase inhibitor, LU 41.453, inhibited the thrombin-induced eicosanoid release, but did not reduce the mobilization of arachidonate and the formation of eicosanoids caused by methyl mercury. This confirms that eicosanoid release is secondary to platelet activation by thrombin, whereas methyl mercury does not require the activation cascade for its effect on eicosanoid release. The primary effect of $\mathrm{H}_{2} \mathrm{O}_{2}$ and methyl mercury on arachidonate mobilization is also demonstrated by the observation that indomethacin does not suppress the eicosanoid release, although it prevents the $\mathrm{H}_{2} \mathrm{O}_{2}$ and methyl mercury-induced shape change, aggregation and serotonin secretion.

A potent stimulus for eicosanoid release in platelets is an intimate platelet contact (5), an effect which is most pronounced in citrated plasma (52). Therefore, if platelets are allowed to aggregate, their aggregation and secretion response is enhanced as a consequence of $\mathrm{PGH}_{2} / \mathrm{TXA}_{2}$ formation. The aggregation (= contact) can be definitely suppressed by EDTA, which interferes with the binding of the aggregation cofactor, fibrinogen, to its glycoprotein IIb/IIIa receptors on the platelet surface (53). Even in the presence of EDTA, $\mathrm{H}_{2} \mathrm{O}_{2} 2 \mathrm{mmol} / 1$ and methyl mercury $3 \mu \mathrm{mol} / 1$ induced a full shape change and a certain release of serotonin. Thus, these agents were potent stimuli of $\mathrm{PGH}_{2} / \mathrm{TXA}_{2}$ formation, even in the absence of an aggregation-induced secondary mobilization of arachidonate.

Higher concentrations than $2 \mathrm{mmol} / \mathrm{l}$ of $\mathrm{H}_{2} \mathrm{O}_{2}$ and $3 \mu \mathrm{mol} / 1$ of methyl mercury were not used for specific stimulations of the eicosanoid release, because of certain side effects. $\mathrm{H}_{2} \mathrm{O}_{2}(5-30 \mathrm{mmol} / \mathrm{l})$ still enhanced the eicosanoid release and 12-HETE production, but suppressed the formation of $\mathrm{TXB}_{2}$ and HHT. This is consistent with the inhibition of the cyclooxygenase observed by Kawaguchi et al. (24) in rabbit platelets. In addition, oxygen bubbles were formed when $\mathrm{H}_{2} \mathrm{O}_{2}$ was present at $\geq 1.5 \mathrm{mmol} / \mathrm{l}$, due to the instability of $\mathrm{H}_{2} \mathrm{O}_{2}$ at high concentrations. When more than 3 or $20 \mu \mathrm{mol} / 1$ of methyl mercury were applied to 200 $\cdot 10^{9} / 1$ or $2 \cdot 10^{12} / 1$ platelets, respectively, shape change and aggregation occurred, despite the presence of indomethacin. In other words, methyl mercury at these high concentrations elicits another platelet-activating effect that is not mediated by the formation and action of $\mathrm{PGH}_{2}$ and $\mathrm{TXA}_{2}$. Even at the highest concentrations tested, lactate dehydrogenase liberation remained below $3 \%$ with $30 \mathrm{mmol} / 1 \mathrm{H}_{2} \mathrm{O}_{2}$ and $4 \%$ with $1 \mathrm{mmol} / 1$ methyl mercury, showing that cell lysis did not occur to an appreciable degree.

The mechanism whereby $\mathrm{H}_{2} \mathrm{O}_{2}$ and methyl mercury selectively trigger the release of arachidonate remains to be elucidated. In platelets, free arachidonate is liberated mainly by phospholipase $A_{2}$ activated by cytoplasmic $\mathrm{Ca}^{2+}$, which increases during platelet ac- 
tivation (54). This mechanism is thought to be operative in the thrombin-induced eicosanoid release (55, 56) but is unlikely to be involved in the eicosanoid release induced by $\mathrm{H}_{2} \mathrm{O}_{2}$ or methyl mercury. A small rise in cytoplasmic $\mathrm{Ca}^{2+}$ is sensitively reflected by a spherization of the platelets (57). In platelets exposed to acetylsalicylic acid however, no shape change is observed upon stimulation with $\mathrm{H}_{2} \mathrm{O}_{2}$ or methyl mercury, despite considerable arachidonate release. Whether $\mathrm{H}_{2} \mathrm{O}_{2}$ or methyl mercury exert a direct, $\mathrm{Ca}^{2+}$ independent effect on the phospholipase $\mathrm{A}_{2}{ }^{2}$ ) activity or interfere with the reacylating pathway of arachidonate is currently under investigation in our laboratory. Both the phospholipase $\mathrm{A}_{2}$ (58) and the reacylating enzymes, arachidonyl-CoA synthetase ${ }^{2}$ ) (16) and lysophospholipid acyltransferase ${ }^{2}$ ) (17), have high activities in platelet membranes, which suggests a high turnover rate of arachidonate deacylation and reacylation. Under these conditions, an inhibition of the reacylating enzymes could just as well lead to a rise in free arachidonate, as to an activation of the phospholipase $A_{2}$. Since in contrast to thrombin and other

\section{References}

1. Lapetina, E. G., Chandrabose, C. J. \& Cuatrecasas, P. (1987) Ionophore A23187- and thrombin-induced platelet aggregation: independence from cyclooxygenase products. Proc. Natl. Acad. Sci. USA 75, 818-822.

2. Rittenhouse, S. E. (1984) Activation of human platelet phospholipase $C$ by ionophore A23187 is totally dependent upon cyclo-oxygenase products and ADP. Biochem. J. 222, $103-110$.

3. Hamberg, M., Svensson, J., Wakabayashi, T. \& Samuelsson, B. (1974) Isolation and structure of two endoperoxides that cause platelet aggregation. Proc. Natl. Acad. Sci. USA $71,235-349$.

4. Hamberg, M., Svensson, J. \& Samuelsson, B. (1975) Thromboxanes: a new group of biologically active compounds derived from prostaglandin endoperoxides. Proc. Natl. Acad. Sci. USA 72, 2994-2998.

5. Holmsen, H. (1980) Mechanisms of platelet secretion, In: Platelets: cellular response mechanism and their biological significance (Rotman, A., Meyer, F. A., Gitler, C. \& Silberberg, A., eds.) pp. 249-263, John Wiley \& Sons Ltd, Chichester (UK).

6. Armstrong, R. A., Jones, R. L. \& Wilson, N. H. (1983) Ligand binding to thromboxane receptors of human platelets: correlation with biological activity. Br. J. Pharmacol. 79, 953-964.

7. Lands, W. E. \& Samuelsson, B. (1968) Phospholipid precursors of prostaglandins. Biochim. Biophys. Acta 164, 426-429.

8. Buchanan, M. R., Butt, R. W., Hirsh, J., Markham, B. A. \& Nazir, D. J. (1986) Role of lipoxygenase metabolism in platelet function: effect of aspirin and salicylate. Prostaglandines Leukotrienes and Medicine 21, 157-168.

9. Marcus, A. J., Broekman, M. J., Safier, L. B., Ullman, H. L. \& Islam, N. (1982) Formation of leukotrienes and other hydroxy acids during platelet-neutrophil interactions in vitro. Biochem. Biophys. Res. Commun. 109, 130-137.

10. Crouch, M. F. \& Lapetina, E. G. (1988) No direct correlation between $\mathrm{Ca}^{2+}$ mobilization and dissociation of $\mathrm{G}_{i}$ during platelet phospholipase activation. Biochem. Biophys. Res. Commun. 153, $21-30$. physiological agonists, $\mathrm{H}_{2} \mathrm{O}_{2}$ and methyl mercury have a direct effect on arachidonate release, these agents are valuable tools for investigating the biochemical mechanism of arachidonate mobilization. Irrespective of whether their target(s) is (are) located within the phospholipase $A_{2}$ or the reacylation pathway, they provide models which not only permit the study of the regulation of free aráchidonate in platelets, but also provide an experimental approach to its specific inhibition. Specific drugs that suppresss arachidonate mobilization by an inhibitory effect on phospholipase $\mathrm{A}_{2}$ or a stimulating effect on the reacylating enzymes are not yet available. The use of specific stimuli of arachidonate release, such as $\mathrm{H}_{2} \mathrm{O}_{2}$ and methyl mercury, should facilitate the search for and the characterization of selective inhibitors of arachidonate release.

\section{Acknowledgement}

The authors thank Rita Wipplinger and Ute Thömen for their expert technical assistance. This work was supported by the Deutsche Forschungsgemeinschaft, $\mathrm{Pa} 263$.
11. Mouco, G. (1987) Phospholipids: release of arachidonate for prostaglandin and thromboxane synthesis. In: Platelet

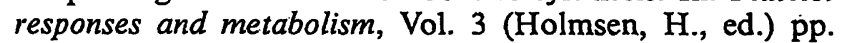
101 - 119, CRC Press Inc., Boca Raton (UंSA).

12. Dise, C. A., Burch, J. W. \& Goodman, D. B. (1982) Direct interaction of mepacrine with erythrocyte and platelet membrane phospholipid. J. Biol. Chem. 257, $4701-4704$.

13. Bills, T. K., Smith, J. B. \& Silver, M. J. (1977) Selective release of arachidonic acid from the phospholipids of human platelets in response to thrombin. J. Clin. Invest. 60 , $1-6$.

14. McKean, M. L., Smith, J. B. \& Silver, M. J. (1981) Formation of lysophosphatidylcholine by human platelets in response to thrombin. J. Biol. Chem. 256, 1522-1524.

15. Mahadevappa, V. G. \& Holub, B. J. (1986) Diacylglycerol lipase pathway is a minor source of released arachidonic acid in thrombin-stimulated human platelets. Biochem. Biophys. Res. Commun. 134, 1327-1333.

16. Wilson, D. B., Prescott, S. M. \& Majerus, P. W. (1982) Discovery of an arachidonyl coenzyme A synthetase in human platelets. J. Biol. Chem. 257, 3510-3515.

17. McKean, M. L., Smith, J. B. \& Silver, M. J. (1982) Phospholipid biosynthesis in human platelets. Formation of phosphatidylcholine from 1-acyl lysophosphatidylcholine by acyl-CoA:1-acyl-sn-glycero-3-phosphocholine acyltransferase. J. Biol. Chem. 257, 11278-11283.

18. Lands, W. E. (1979) In: Geometrical and positional fatty acid isomers (Emken, E. A. \& Dutton, H. J., eds.) pp. $181-$ 212, American Oil Chemists Society, Champaign (USA).

19. Körner, C. F., Hausmann, G., Gemsa, D. \& Gesch, K. (1984) Rate of prostaglandin synthesis is not controlled by phospholipase A activity but by reincorporation of released fatty acids into phospholipids. Agents and Actions 15, $28-30$.

20. Root, R. K., Metcalf, J., Oshino, N. \& Chance, B. (1975) $\mathrm{H}_{2} \mathrm{O}_{2}$ release from granulocytes during phagocytosis. J. Clin. Invest. $55,945-9.55$.

21. Levine, P. H., Weinger, R. S., Simon, J., Scoon, K. L. \& Krinsky, N. I. (1976) Leukocyte-platelet interaction. Release of hydrogen peroxide by granulocytes as a modulator of platelet reactions. J. Clin. Invest. 57, 955-963. 
22. Finazzi-Agro, A., Menichelli, A., Persiani, M., Biancini, G. \& DelPrincipe, D. (1982) Hydrogen peroxide release from human blood platelets. Biochim. Biophys. Acta 718, $21-25$.

23. Zoukas, E., Fäldt, R. \& Ankerst, J. (1985) Effect of latexstimulated granulocytes on platelet aggregation in man. Haemostasis 15, 176-181.

24. Kawaguchi, H., Ishibashi, T. \& Imai, Y. (1982) Increased thromboxane $\mathrm{B}_{2}$ biosynthesis in platelets. Lipids $17,577-$ 587.

25. DelPrincipe, D., Menichelli, W., DeMatteis, W., DiCorpo, M. L., DiGiulio, S. \& Finazzi-Agro, A. (1985) Hydrogen peroxide has a role in the aggregation of human platelets. FEBS Lett. 185, 142-146.

26. Kulmacz, R. J. (1986) Prostaglandin H synthase and hydroperoxides: peroxidase reaction and inactivation kinetics. Arch. Biochem. Biophys. 249, 273-285.

27. Patscheke, H., Paschen, W. \& Wörner, P. (1978) Superoxideindependent platelet response to xanthine oxidase. HoppeSeyler's Z. Physiol. Chem. 359, 933-937.

28. Wörner, P., Patscheke, H. \& Paschen, W. (1979) Response of platelets exposed to potassium tetraperoxochromate, an extracellular source of singlet oxygen, hydoxyl radicals, superoxide anions and hydrogen-peroxide. Hoppe-Seyler's Z. Physiol. Chem. 360, 559-570.

29. Patscheke, H. (1985) Thromboxane synthase inhibition potentiates washed platelet activation by endogenous and exogenous arachidonic acid. Biochem. Pharmacol. 34, $1151-1156$

30. Miller, M. W. \& Clarkson, T. W. (1973) Mercury, mercurials and mercaptans, Charles C. Thomas, Springfield (USA).

31. Storm, D. R. \& Gunsalus, R. P. (1974) Methyl mercury is a potent inhibitor of adenyl cyclase. Nature (London) 250 , $778-779$.

32. MacFarlane, D. E. (1981) The effects of methylmercury on platelets. Induction of aggregation and release via activation of the prostaglandin synthesis pathway. Molec. Pharmacol. 19, 470-476.

33. Ally, A. I. \& Miller, D. R. (1984) The effect of methylmercuric chloride on arachidonic acid metabolism by platelet lipoxygenase. Prostaglandins Leukotrienes and Medicine 15, 209-221.

34. Meydani, M., Meydani, S. M. \& Hathcock, J. N. (1984) Effects of dietary methionine, methylmercury and atrazine on ex-vivo synthesis of prostaglandin $E_{1}$ and thromboxane $\mathrm{B}_{2}$. Prostaglandins Leukotrienes and Medicine 14, 257278.

35. Patscheke, H. (1981) Shape and functional properties of human platelets washed with acid citrate. Haemostasis 10 , 14-27.

36. Born, G. V. R. (1962) Aggregation of blood platelets by adenosine diphosphate and its reversal. Nature 194, $927-$ 929.

37. Marquardt, D. W. (1963) An algorithm for least-squares estimation of nonlinear parameters. J. Soc. Indust. Appl. Math. $11,431=441$.

38. Tabata, T. \& Ito, R. (1975) Effective treatment of the interpolation factor in Marquardt's nonlinear least-squares fit algorithm. Computer Journal 18, 250-251.

39. Nugteren, D. H. \& Hazelhof, E. (1973) Isolation and properties of intermediates in prostaglandin biosynthesis. Biochim. Biophys. Acta 326, 448-461.

40. Nugteren, D. H. \& Christ-Hazelhof, E. (1980) Chemical and enzyme conversions of the prostaglandin endoperoxide PGH 2 . Adv. Prostaglandin Thromboxane Res. 6, 129-137.

41. Diczfalusy, U., Falardeau, P. \& Hammarström, S. (1977) Conversion of prostaglandin endoperoxides to $C_{i j}$-hydroxy acids catalyzed by human platelet thromboxane synthase. FEBS Lett. 84, 271-274.
42. Haurand, M. \& Ullrich, V. (1985) Isolation and characterization of thromboxane synthase from human platelets. $J$. Biol. Chem. 260, 15059-15067.

43. Patschekc, H. \& Stegmeier, K. (1984) Investigations on a selective non-prostanoic thromboxane antagonist, BM 13.177, in human platelets. Thromb. Res. 33, 277-288.

44. Patscheke, H., Hornberger, W. \& Stegmeier, K. (1985) Blockade of the human platelet thromboxane $A_{2}$ receptor by 4-(2-(p-chlorbenzene)sulphonylamino)-ethylbenzene acetic acid (BM 13.505), International Symposium on Leukotrienes and Prostanoids in Health and Disease, Oct. 20-25, 1985, Tel Aviv, p. 11.

45. Mais, D., Saussy, D., Chaikhouni, A., Kochel, P., Knapp, D., Hamanaka, N. \& Halushka, P. (1985) Pharmacologic characterization of human and canine thromboxane $\mathrm{A}_{2}$ / prostaglandin $\mathrm{H}_{2}$ receptors in platelets and blood vessels: evidence for different receptors. J. Pharmacol. Exp. Ther. $233,418-424$

46. Smith, J. B. \& Willis, A. L. (1971) Aspirin selectively inhibits prostaglandin production in human platelets. $\mathrm{Na}$ ture [New Biol.] 231, 235-237.

47. Kaibuchi, K., Takai, Y., Sawamura, M., Hashijama, M., Fujikura, T. \& Nishizuka, Y. (1983) Synergistic functions of protein phosphorylation and calcium mobilization in platelet activation. J. Biol. Chem. 258, 67.01-6704.

48. Authi, K. S. \& Crawford, N. (1985) Inositol 1,4,5-trisphosphate-induced release of sequestered $\mathrm{Ca}^{2+}$ from highly purified human platelet intracellular membranes. Biochem. J. 230, 247-253.

49. Tateson, J. E., Moncada, S. \& Vane, J. R. (1977) Effects of prostacyclin (PGX) on cyclic AMP concentrations in human platelets. Prostaglandins 13, 389-399.

50. Gorman, R. R., Bunting, S. \& Miller, O. V. (1977) Modulation of human platelet adenylate cyclase by prostacyclin (PGX). Prostaglandins 13, 377-389.

51. Stürzebecher, C. S. \& Losert, W. (1987) Effects of iloprost on platelet activation in vitro. In: Prostacyclin and its Stable Analogue Iloprost (Gryglewski, R. J. \& Stock, G., eds.) pp. 39-51, Springer-Verlag, Berlin, F. R. G.

52. Mustard, J. F., Perry, D. W. \& Kinlough-Rathbone, R. L. (1975) Factors responsible for ADP induced release reaction of human platelets. Amer. J. Physiol. 228, 1757- 1765.

53. Parise, L. V. \& Phillips, D. R. (1985) Reconstitution of the purified platelet fibrinogen receptor: fibrinogen binding properties of the glycoprotein IIb-IIIa complex. J. Biol. Chem. 260, 10689-10707.

54. Withnall, M. T., Brown, T. S. \& Diocee, B. K. (1984) Calcium regulation of phospholipase $A_{2}$ is independent $0_{i}^{*}$ calmodulin. Biochem. Biophys. Res. Commun. 121, 507513.

55. Rittenhouse, S. E. \& Horne, W. C. (1984) Ionomycin can elevate intraplatelet $\mathrm{Ca}^{2+}$ and activate phospholipase $\mathrm{A}$ without activating phospholipase C. Biochem. Biophys. Res. Commun. 123, 393-397.

56. Pollok, W. K., Irvine, R. F. \& Rink, T. J. (1986) Free $\mathrm{Ca}^{2+}$ requirements of agonist-induced thromboxane $A_{2}$ synthesis in human platelets. Eur. J. Pharmacol. 132, 309-312.

57. Hallam, T. J. \& Rink, T. J. (1985) Responses to adenosine diphosphate in human platelets loaded with the fluorescent calcium indicator quin2. J. Physiol. (London) 386, 131 146.

58. Kramer, R. M., Checani, G. C., Deykin, A., Pritzker, C. R. \& Deykin, D. (1986) Solubilization and properties of $\mathrm{Ca}^{2+}$-dependent human platelet phospholipase $\mathrm{A}_{2}$. Biochim. Biophys. Acta 878, 394-403.

Wilfried Hornberger, Dipl.-Biol.

Institut für Klinische Chemie

Klinikum Mannheim der Universität Heidelberg Postfach 100023

D-6800 Mannheim 1 
